A RCHIWA, BIBLIOTEKI

I MUZEA KOŚCIELNE 110 (2018)

https://doi.org/10.31743/abmk.2018.110.10

RADOSŁAW FRANCZAK* - POZNAŃ

\title{
SUPEREKSLIBRISY DWÓCH RENESANSOWYCH BIBLIOFILÓW NA OPRAWACH INKUNABULÓW Z DAWNEJ BIBLIOTEKI BENEDYKTYNÓW W LUBINIU ${ }^{1}$
}

Jeden z najstarszych na ziemiach polskich klasztor benedyktynów w Lubiniu posiadał w początkach XIX w. zbiory liczące ponad 5.000 woluminów ${ }^{2}$. Analiza sporządzonego w $1837 \mathrm{r}$. katalogu pozwala szacować, że przeszło 110 egzemplarzy tego księgozbioru stanowiły inkunabuły ${ }^{3}$. W następstwie kasacji klasztoru w 1836 r., zasoby biblioteki zostały podzielone i uległy całkowitemu rozproszeniu. W 1862 r. ok. 1.500 woluminów, w tym kilkadziesiąt inkunabułów, przeniesiono do Biblioteki Seminaryjnej w Gnieźnie, która obecnie współtworzy zbiory tamtejszego Archiwum Archidiecezjalnego (dalej: AAG) ${ }^{4}$. W trakcie prowadzonej kwerendy w AAG piszący te słowa zwrócił uwagę na dwa inkunabuły z dawnej biblioteki benedyktynów w Lubiniu, które wyróżniają wyciśnięte na ich oprawach superekslibrisy.

Właścicielem pierwszego woluminu był Piotr Wedelicjusz z Obornik (14831544) bibliofil, nadworny lekarz króla Zygmunta Starego oraz królowej Bony5.

* Radosław Franczak - mgr historii; doktorant w Instytucie Historii, Uniwersytet Adama Mickiewicza w Poznaniu; e-mail: rad.fran7@gmail.com

ORCID 0000-0002-1603-629X

${ }^{1}$ Praca powstała w ramach projektu Inwentaryzacja zbiorów Biblioteki Katedralnej w zasobach Archiwum Archidiecezjalnego w Gnieźnie, finansowanego z Narodowego Programu Rozwoju Humanistyki MNiSW (nr 11H 120179 81). Kierownikowi projektu dr. hab. Piotrowi Pokorze autor składa wyrazy podziękowania za wszelką pomoc.

${ }^{2}$ J. Ostrowski, Bibljoteka Klasztoru Benedyktynów w Lubiniu, w: Bibljoteki Wielkopolskie i Pomorskie, red. S. Vrtel-Wierczyński, Poznań 1929, s. 175-176; J. Urban, Nowożytna biblioteka opactwa benedyktynów w Lubiniu, „Zeszyty Lubińskie”, 2 (1992) s. 23-24.

${ }^{3}$ Archiwum Archidiecezjalne w Poznaniu (dalej: AAP): Rejencja w Poznaniu, sygn. 3912.

${ }^{4}$ Zob. L. Formanowicz, Katalog inkunabułów biblioteki kapitulnej w Gnieźnie, Poznań 1939; J. Rył, Katalog inkunabułów zespołu Seminaryjnego Biblioteki Katedralnej w Gnieźnie, „Archiwa Biblioteki i Muzea Kościelne" (dalej: ABMK), 25 (1972) s. 115-208; J. Wojtkowski, Rekonstrukcja drugiego zeszytu katalogu inkunabułów Biblioteki Kapitulnej w Gnieźnie księdza Leona Formanowicza, Lublin 1969.

${ }^{5}$ K. Miaskowski, Piotr Wedelicjusz z Obornik, „Rocznik Towarzystwa Przyjaciół Nauk w Poznaniu", 34 (1908) s. 169-212. 
Należące do niego znaki własnościowe zostały dodane na oprawie druku Sermones autorstwa Bernarda Claravallensis wydanego w 1495 r. ${ }^{6}$ Po upływie lat, z oprawy zachowała się jedynie brązowa skóra ze zdobieniami oraz z widocznymi śladami pary zapięć na dłuższych krawędziach. Dekorację oprawy woluminu wykonano metodą na złoto i ślepo za pomocą tłoków i strychulca. Na górnej okładzinie gotycką ramę zdobi bukiet $\mathrm{z}$ trzech kwiatów, monogram IHS w narożach oraz litery tworzące tytuł i autora dzieła (,Sz bernardi”). Listwy z wyciskami banderoli z inskrypcją ,MAR[IA]" obejmują zwierciadło, w którym wyciśnięto pędy ruty i kwiatony (il. 1). Niemal identycznie wykonano kompozycję i zdobienia dolnej okładziny z niewielką różnicą. Listwy zastąpiono ramą gotycką i nie zastosowano wycisków literniczych (il. 2). Pięć garbów zwięzów ujęto z kolei liniami strychulcowymi. Oddzielone w ten sposób kompartymenty ozdobiono wyciskami pędu ruty i kwiatonu.

W późniejszym czasie na dotychczasowe zdobienia nałożono nowe elementy. $\mathrm{Na}$ górnej okładzinie pod inskrypcją oznaczającą tytuł i autora umieszczono dodatkowy antykwowy napis ,SER[MONES]: $B$ [EA]TI BERNARDI'. W centrum zwierciadła naniesiono wycisk superekslibrisu Piotra Wedelicjusza z Obornik o rozmiarach $41 \times 47 \mathrm{~mm}$ w postaci herbu Wedel w italianizującej tarczy z dwoma wcięciami u nasady o wolutowych bokach i spięciu na środku (il. 3) ${ }^{7}$. Po obu jego stronach umieszczono dwa mniejsze wyciski superekslibrisu Wedelicjusza (śr. $16 \mathrm{~mm}$ ) o formie owalnej pieczęci sygnetowej z jego herbem i inicjałami $P[\mathrm{e}-$ trus] $V$ [edelicius] $\| D$ [e] $O$ [borniky] (il. 4). Na dolnej okładzinie wyciśnięto tylko większy z superekslibrisów oraz napis powyżej „D[omini] PETRII VEDELICII”. Całości zdobień dopełniają wyciski listka na obu okładzinach.

Zastosowane narzędzia, wskazują, że druk oprawił „Introligator dwóch Mszałów Krakowskich" działający w Krakowie na przełomie XV i XVI w. ${ }^{8}$ Leon Formanowicz w swoim katalogu określił czas powstania oprawy na lata ok. 1498$1502^{9}$. Niestety nie wiadomo na jakiej podstawie ustalił tak dokładny okres jej sporządzenia, który bezsprzecznie można datować po $1495 \mathrm{r}$. do początków XVI w. W innym już warsztacie dodano wtórnie wyciski superekslibrisów, liter oraz listków. Badane znaki własnościowe należą do grupy przynajmniej siedmiu odmian superekslibrisów herbowych i napisowych Piotra Wedelicjusza ${ }^{10}$. Superekslibris

\footnotetext{
${ }^{6}$ Archiwum Archidiecezjalne w Gnieźnie (dalej: AAG): sygn. Inc. 241, Bernardus Claravallensis, Sermones de tempore et de sanctis et de diversis, Nicolaus Kessler, Basel 1495; zob. L. Formanowicz, Katalog inkunabułów biblioteki kapitulnej w Gnieźnie, Poznań 1939, s. 26 nr 88.

${ }^{7} \mathrm{Na}$ temat tej formy tarczy zob. Wagner, Superekslibris polski. Studium o kulturze bibliofilskiej i sztuce od średniowiecza do połowy XVII wieku, Toruń 2016., s. 261.

${ }^{8}$ A. Lewicka-Kamińska, $Z$ dziejów opraw staropolskich, msp, Biblioteka Jagiellońska, sygn. Przyb. 33/80, s. 160-161.

${ }^{9}$ Formanowicz, Katalog, s. $26 \mathrm{nr} 88$.

${ }^{10}$ Wagner, Superekslibris polski, s. 188. Dawny pogląd mówił o sześciu rodzajach superekslibrisów zob. E. Chwalewik, Exlibrisy polskie szesnastego i siedemnastego wieku, Wrocław 1955, s. 56 i 94; K. Sokołowska-Grzeszczyk, Znaki książkowe lekarzy polskich, „Archiwum Historii Medycyny”, 44 (1981) z. 1, s. 25.
} 
$\mathrm{z}$ h. Wedel w italianizującej tarczy znany jest $\mathrm{z}$ większej ilości opraw ${ }^{11}$, niż drugi w formie sygnetowej zastosowany na co najmniej dwóch oprawach ${ }^{12}$. Natomiast superekslibris napisowy pojawia się z kolei na kilku egzemplarzach ${ }^{13}$. Dwa pierwsze znaki własnościowe znane są przede wszystkim z opraw sporządzonych w krakowskim warsztacie należącym do Mistrza Główek Anielskich czyli Macieja z Przasnysza ${ }^{14}$. Z kolei analiza złoconych listków na oprawie świadczy, że zostały one wyciśnięte narzędziem stosowanym właśnie przez ten warsztat (tłoki „listek”) ${ }^{15}$. W nawiązaniu do powyższych argumentów należy przyjąć tezę o dodaniu superekslibrisów oraz pozostałych wycisków przez Mistrza Główek Anielskich. Niestety nie jest możliwe ustalenie dokładnego czasu ich wytłoczenia, czego nie ułatwia brak daty na oprawie czy też brak informacji we wpisie proweniencyjnym. Jednak badania nad superekslibrisami, pozwalają wysunąć przypuszczenie, że znak własnościowy $\mathrm{z} \mathrm{h}$. Wedel w italianizującej tarczy wyciśnięto za pomocą tłoku pochodzącego z przełomu lat 20/30. XVI w. ${ }^{16}$ Przyjmując takie przypuszczenie - czas umieszczenia superekslibrisów należałoby zawęzić do okresu od końca trzeciej dekady szesnastego stulecia do 1544 r., czyli daty śmierci Piotra Wedelickiego.

Oprócz znaków własnościowych oraz proweniencji Wedelicjusza, wewnątrz woluminu znajduje się kilka wpisów. Jeden z nich informuje, że w 1599 r.

${ }^{11}$ AAG, sygn.: Inc. 211, Inc. 212; AAP, sygn. Inc. 305; Biblioteka Uniwersytecka w Poznaniu (dalej: BUP), sygn. SD3463 III; P. Pokora, M. Muraszko, Skarby drukarstwa i introligatorstwa ze zbiorów dawnej Biblioteki Katedralnej w Gnieźnie. Katalog wystawy w Bibliotece Raczyńskich w Poznaniu, Poznań 5-30 maja 2015, Poznań-Gniezno 2015, s. 20, il. nienum.; Wagner, Superekslibris, s. 188.

${ }^{12}$ Pierwszy przechowywany jest w zbiorach AAP, sygn. 305; por. K. Kantak, Spis ksiązek z XV wieku Ksiąznicy Seminarjum Duchownego w Poznaniu. Część pierwsza (dokończenie), „Rocznik Towarzystwa Przyjaciół Nauk Poznańskiego”, 46 (1919) nr 248). Drugi egzemplarz znajduje się w Petersburgu i znany jest mi tylko z literatury (A. Hobson, Humanists and bookbinders, Cambridge 1992, s. 129, il. 102; Wagner, Superekslibris, s. 206-207, 234, il. 73).

${ }^{13}$ Zob. m.in. AAGn., sygn. BK974; BUP, sygn. SD3463 III; Pokora, Muraszko, Skarby,s. 20, il. nienum; Sokołowska-Grzeszczyk, Znaki, s. 28, ryc. 4; Wagner, Superekslibrisy, s. 289.

${ }^{14} \mathrm{~W}$ warsztacie Macieja z Przasnysza tymi superekslibrisami oprawiono następujące woluminy: AAG, sygn. BK974, Inc. 212; BUP, sygn. SD3463 III; Pokora, Muraszko, Skarby drukarstwa $i$ introligatorstwa ze zbiorów dawnej Biblioteki Katedralnej w Gnieźnie, s. 20, il. nienum; Mistrz Główek Anielskich wykonał także inne oprawy dla Piotra Wedelickiego zob. m.in. Biblioteka Poznańskiego Towarzystwa Przyjaciół Nauk (dalej: Biblioteka PTPN), sygn. 11642. I adl. 11643. I; por. http://www.ptpn.poznan.pl/oprawy/ (dostęp: 20.04.2017);

J.S. van Leeuwen, The Golden Age of Bookbindings in Cracow 1400-1600, Kraków 2011, s. 115 tabl. 39; Sokołowska-Grzeszczyk, Znaki, s. 27-28 ryc. 3-4.

${ }^{15}$ Biblioteka PTPN, sygn. 11642. I adl. 11643. I; por. http://www.ptpn.poznan.pl/oprawy/ (dostęp: 20.04.2017); Sokołowska-Grzeszczyk, Znaki, s. 27-28 ryc. 3-4.

${ }^{16} \mathrm{Na}$ tę hipotezę wskazuje kilka woluminów. Dwa z nich posiadają na okładzinach wyciśnięty rok sporządzenia oprawy: pierwszy z egzemplarzy zaopatrzony jest w datę „1534” (AAGn., sygn. Inc. 212) , a drugi w „1538” (BUP, sygn. SD3463 III). Kolejny egzemplarz został oprawiony po 1531 r., na co wskazuje rok wydania druku (AAGn., sygn. BK974). W innym przypadku (AAGn., sygn. Inc. 211) datę wykonania oprawy określono w literaturze na ok. 1530 r. (zob. Formanowicz, Katalog, nr 129; Wagner, Superekslibris, s. 289-290). 
w Poznaniu wolumin zakupił Marcin Kowieski, zakonnik lubiński oraz proboszcz w Starym Gostyniu ${ }^{17}$. Następny wpis świadczy, że niedługo po tym egzemplarz został własnością opata lubińskiego Stanisława Kiszewskiego ${ }^{18}$, a po jego śmierci pozostał w klasztorze. Nie jest jasne, kiedy i jak wolumin opuścił księgozbiór Wedelickiego oraz co się z nim działo do 1599 r. Wiadomo, że wiele ksiąg po śmierci Piotra odziedziczył jego brat Jakub, kanonik poznański. Następnie miały one trafić do biblioteki kapitulnej w Poznaniu oraz kolegium jezuickiego. Prawdopodobnie inną część księgozbioru przejął po śmierci Piotra Wedelicjusza kupiec poznański Szymon Quittemberg ${ }^{19}$.

Kolejne interesujące superekslibrisy znajdują się na oprawie Confessionale autorstwa Antoninusa Florentinus wydanego w 1496 r. w Strassburgu ${ }^{20}$. Druk ochraniany przez deski i brązową skórę, zaopatrzono w parę zapięć na dłuższych krawędziach. Na okładzinie górnej kompozycję oparto na dwóch ramach, które oddzielają listwy ozdobione przez wyciski podwójnych pelt. Zewnętrzną bordiurę pozostawiono pustą, natomiast w wewnętrznej umieszczono dwa wyciski h. Godziemba w tarczy $(22 \times 24 \mathrm{~mm})$. Znajdują się one w szerszych polach dolnej i górnej części ramy. Zwierciadło podzielono dość niezręcznie liniami strychulcowymi na kilka pól w kształcie trójkąta oraz rombu, w których umieszczono wyciski rozety w romboidalnej ramie oraz jednego kwiatonu (il. 5). Na dolnej okładzinie również utworzono dwie ramy, z czego zewnętrzną pozostawiono pustą, a wewnętrzną przyozdobiono wyciskami wspomnianego kwiatonu. Zwierciadło, podobnie jak na okładzinie górnej, podzielono na kilka trójkątnych bądź romboidalnych pól i wypełniono je wyciskami rozet w rombie (il. 6). Z kolei garby czterech wydatnych zwięzów wydzielono liniami strychulcowymi. Wyznaczone w ten sposób kompartymenty przyozdabia motyw floralny.

Niniejszą oprawę wyróżniają wyciski z h. Godziemba, których nie notowała w swoim katalogu J. Rył (il. 7) ${ }^{21}$. Na ich właściciela mogą wskazywać analogiczne wyciski na oprawie woluminu z Biblioteki Seminarium Duchownego we Włocławku, opisywanego przez A. Wagnera ${ }^{22}$. Egzemplarz, znajdujący się niegdyś u bernardynów w Kazimierzu Biskupim, zawiera wpis z 1533 r. informujący

${ }^{17}$ Formanowicz, Katalog, s. 26 nr 88; L. Sobkowski, O Benedyktynach Lubińskich w Starym Gostyniu, Poznań 1912, s. 14 nr 27.

${ }^{18}$ S. Grzybowski, Kiszewski Stanisław, w: Polski Stownik Biograficzny (dalej: PSB), t. 31, Kraków-Warszawa-Wrocław 1966-1967, s. 507; A. Jezierski, Klasztor benedyktyński w Lubiniu, Poznań 1915, s. 30-33; B. Urban, Opat Lubiński Stanisław Kiszewski w świetle kroniki Barttomieja z Krzywinia, „Zeszyty Lubińskie”, 2 (1992) s. 28-38.

${ }^{19}$ M. Radojewski, Nieznany ekslibris Piotra Wedelicjusza - najstarszy polski znak lekarski, ,Ze Skarbca Kultury”, 28 (1977) s. 51-58; Sokołowska-Grzeszczyk, Znaki, s. 25-26; Wagner, Superekslibris, s. 187-188.

${ }^{20}$ AAGn., sygn. Inc. 116; zob. Rył, Katalog inkunabułów zespołu Seminaryjnego Biblioteki Katedralnej w Gnieźnie, $\mathrm{nr} 31$.

${ }^{21}$ Tamże.

${ }^{22}$ A. Wagner, Inkunabut w oprawie z superekslibrisami Biskupa Jana Lubrańskiegona na tle introligatorstwa krakowskiego i poznańskiego końca XV-początku XVI w., ABMK, 102 (2014) s. 301325; tenże, Relikt humanistycznego księgozbioru, „Spotkania z Zabytkami”, 5-6 (2013) s. 60-62; tenże, Superekslibris polski. Studium o kulturze bibliofilskiej i sztuce od średniowiecza do połowy 
o jego nabyciu przez biskupa poznańskiego i bibliofila Jana Lubrańskiego (1456$1520)^{23}$. Niniejsze wyciski z h. Godziemba uznano w związku z tym za superekslibris hierarchy, który musiał zakupić księgę przed swoją śmiercią w 1520 r. Ta następnie trafiła do klasztoru w Kazimierzu Biskupim, gdzie w 1533 r. nadano stosowny wpis $^{24}$. Za słusznością tezy A. Wagnera o związku superekslibrisu z Janem Lubrańskim przemawia także identyczny wycisk $\mathrm{z}$ h. Godziemba na poznańskiej księdze czynności biskupich z lat 1516-152025. W tym wypadku nie spełniał on roli superekslibrisu, lecz informuje o sprawowaniu rządów biskupich w tym czasie przez Lubrańskiego ${ }^{26}$. W związku z tym analiza powyższych wycisków, również pod względem wymiarów pozwala stwierdzić, że są one identyczne jak te na egzemplarzu Confessionale i wykonano je za pomocą jednego tłoka. Na tej podstawie wydaje się, słuszne przypuszczenie że znak własnościowy na woluminie z klasztoru w Lubiniu mógł należeć do Jana Lubrańskiego, który znany ze swoich bibliofilskich zamiłowań pozostawił księgozbiór liczący co najmniej 151 $\mathrm{ksiąg}^{27}$. Niestety opisany wolumin nie znajduje się w sporządzonym po śmierci biskupa inwentarzu, co jednak nie wyklucza, że egzemplarz ten mógł należeć do niego przez pewien czas $^{28}$.

Analiza wycisków pozostałych narzędzi przynosi dodatkowe wnioski dotyczące miejsca oprawienia woluminu. Spośród nich uwagę zwraca przede wszystkim dekorujący oprawę kwiaton (tłoki „kwiaton”). Z pewnością wyciśnięto go tłokiem, którym posługiwano się w pracowni introligatora z gmerkiem ,małpki ze zwierciadłem"- warsztatu uznanego przez L. Formanowicza i A. Lewicką-Kamińską za działający w Poznaniu ${ }^{29}$. Oczywiście wyciski jednego narzędzia nie muszą przesądzać o wykonaniu oprawy przez tego introligatora, lecz powyższej hipotezie sprzyjają dodatkowe dowody. Mianowicie w zbiorach AAG natrafiono na jeszcze jeden wolumin z identycznymi superekslibrisami Jana Lubrańskiego. Druk wydany w 1515 r. ochrania oprawa wykonana niewątpliwie w warsztacie

XVII wieku, Toruń 2016, s. 163, 197, 198, 491. Dziękuję dr. Arkadiuszowi Wagnerowi za udostępnienie fotografii egzemplarza z Wyższego Seminarium Duchownego we Włocławku.

${ }^{23}$ L. Hajdukiewicz, Lubrański Jan h. Godziemba, PSB, t. 17, Wrocław-Warszawa-Kraków-Gdańsk 1973, s. 81-84.

${ }^{24}$ Wagner, Inkunabut, s. 301-325; tenże, Relikt, s. 60-62; tenże, Superekslibris, s. 163, 197, 198, 491.

${ }^{25}$ AAP, sygn. AE VI. Dziękuję mgr. Jakubowi Łukaszewskiemu za zwrócenie uwagi na niniejszą księgę. Pragnę złożyć mu także dodatkowe wyrazy wdzięczności za udostępnienie woluminu z Biblioteki Uniwersyteckiej w Poznaniu z superekslibrisami Piotra Wedelickiego i wszelką pomoc.

${ }^{26} \mathrm{Na}$ temat różnicy pomiędzy superekslibrisem a wyciskiem herbu urzędnika zob. Wagner, Superekslibris, s. 59.

${ }^{27}$ AAP, sygn. CP 35, 130V.-134V; Acta Capitulorum saeculi XVI selecta, T. I, wyd. B. Ulanowski, Kraków 1894, s. 219-221; zob. A. Ochmańska, Prywatne księgozbiory wielkopolskie XVI w., „Biblioteka”, 2 (1998) s. 23-24; R. Marciniak, Biblioteka biskupa Jana Lubrańskiego, „Kronika Miasta Poznania", 2 (1999) s. 111-126; Wagner, Inkunabut, s. 301-302; tenże, Relikt, s. 60; tenże, Superekslibris, s. 163.

${ }^{28}$ AAP, sygn. CP 35, 130V.-134V; Acta Capitulorum saeculi XVI selecta, T. I, wyd. B. Ulanowski, Kraków 1894, s. 219-221; AAP, sygn. CP 35, 130V.-134V.

${ }^{29}$ BJ, sygn. Przyb 115/80; Formanowicz, Katalog, s. $22 \mathrm{nr} 75$. 
introligatora z gmerkiem „małpka ze zwierciadłem”, na której oprócz m.in. wycisków radełka zoomorficznego oraz kwiatonu i pelt umieszczono charakterystyczny gmerk (il. 8). A. Wagner znający ten egzemplarz, porównał go z woluminem włocławskim i stwierdził, że pod względem cech formalnych obie oprawy pochodzą z tego samego warsztatu, który określał jednak na krakowski lub poznański. Niemniej wydaje się, że za ostatnią lokalizacją warsztatu przemawiają ważne argumenty. Pierwszym $\mathrm{z}$ nich jest makulatura zastosowana przez introligatora z gmerkiem „małpka ze zwierciadłem” w oprawach druków z AAG, którą stanowi dokumentacja spraw z akt czynności konsystorza poznańskiego ${ }^{30}$. Drugim argumentem jest wycisk kwiatonu na oprawie z Biblioteki Seminarium Duchownego we Włocławku, który wykonano za pomocą tłoka należącego prawdopodobnie w końcu XV w. do anonimowego warsztatu poznańskiego (tłoki „kwiaton 2”) ${ }^{31}$. Ostatnim $\mathrm{z}$ argumentów jest podobieństwo pod względem zastosowanych narzędzi na oprawie z Włocławka i księgi czynności biskupów poznańskich. Powtarza się tutaj kompozycja wycisków tłoków tworzących chrystogram w glorii promienistej, wyciski rozety oraz radełka $\mathrm{z}$ ornamentem floralnym arbor vitae i motywem zoomorficznym (zob. tłoki i radełko). W przypadku ksiąg czynności biskupich, oprawiano je przede wszystkim w lokalnym warsztacie, chociaż zdarzały się też odstępstwa od tej reguły ${ }^{32}$. Niniejszy wywód należy jednak uzupełnić pewną dygresją. Dla wszystkich opisanych opraw oprócz inkunabułu lubińskiego wspólne są wyciski radełka $\mathrm{z}$ ornamentem floralnym arbor vitae $\mathrm{z}$ osadzonymi na jego tle zwierzętami. Narzędzie te stosowano w warsztacie introligatora $\mathrm{z}$ gmerkiem „małpka ze zwierciadłem”, lecz bardzo podobne używał również introligator MNS działający w Krakowie od przełomu XV/XVI w. po lata 20. XVI w. A. Lewicka-Kamińska przypuszczała, że radełko było wzorowane na poznańskim lub zostało bezpośrednio przejęte przez krakowski warsztat. Okoliczność ta sprawia, że nie może być ono głównym kryterium w ustalaniu warsztatu i zmusza do większej ostrożności ${ }^{33}$.

Powyższy wywód wskazuje, że najprawdopodobniej wszystkie pozostałe egzemplarze z wyciskami herbu Godziemba zostały wykonane w poznańskim warsztacie introligatora z gmerkiem „małpka ze zwierciadłem”. Zatem przypuszczenie o pochodzeniu oprawy Confessionale z tej samej pracowni wydaje się jak najbardziej słuszne. Określenie dokładnego czasu oprawienia druku nie pozwala brak daty na oprawie oraz brak informacji na ten temat $\mathrm{w}$ proweniencji. $\mathrm{W}$ tej kwestii istotna jest analiza samego superekslibrisu hierarchy, jak w przypadku

${ }^{30}$ AAG, sygn. BK1240, BK6087, BK6457; Jeden z odnalezionych fragmentów zawiera kopię mandatu z 1490 r., prawdopodobnie oficjała i wikariusza generalnego poznańskiego, w którym pozywa kilku kanoników w tym: Mikołaja Czepla i Macieja z Poznania, zob. AAG, sygn. BK6087. Identyfikację wszystkich fragmentów dokonał mgr Jakub Łukaszewski, który odnalazł je wraz z piszącym te słowa.

${ }^{31}$ A. Lewicka-Kamińska, Z dziejów staropolskiej oprawy książkowej, maszynopis/rękopis, BJ, sygn. Przyb. 33/80, s. 168.

${ }^{32}$ Wyjątek stanowi księga czynności biskupów poznańskich za rządów Jana Latalskiego, którą oprawiono u Macieja z Przasnysza w Krakowie, AAP, sygn. AE VII.

${ }^{33}$ Lewicka-Kamińska, $Z$ dziejów, BJ, sygn. Przyb. 36/80, s. 278-280. 
woluminu należącego do Piotra Wedelickiego. W literaturze przedmiotu jedna z hipotez zakłada, że Jan Lubrański mógł używać tego znaku własnościowego przed objęciem biskupstwa płockiego w 1497 r., na co ma wskazywać brak dystynkcji. Należy jednak odrzucić to przypuszczenie o czym świadczą superekslibrisy na oprawie druku z 1515 r. oraz h. Godziemba na księdze czynności biskupów poznańskich z lat 1516-1520. Zatem trzeba przyjąć inną hipotezę A. Wagnera, która mówi o niestosowaniu przez hierarchę insygniów biskupich na superekslibrisie ${ }^{34}$. W tych okolicznościach termin a quo wykonania oprawy stanowi czas wydania druku w 1496 r., natomiast termin ad quem rok 1520, czyli data śmierci Jana Lubrańskiego.

Nie sposób stwierdzić dokładnie kiedy i w jakich okolicznościach wolumin trafił do zbiorów klasztoru benedyktynów w Lubiniu. Możliwe, że podzielił on los części księgozbioru hierarchy, który po jego śmierci trafił do biblioteki kapitulnej w Poznaniu, a następnie uległ rozproszeniu. Ze względu na brak informacji na temat druku Confessionale we wspomnianym wyżej inwentarzu istnieje również możliwość, że wolumin opuścił bibliotekę hierarchy ok. 1520 r. jeszcze za jego życia lub niedługo po jego śmierci przed sporządzeniem spisu. Nie wiadomo, co się z nim działo aż do XVII w., kiedy był już własnością zakonnika z klasztoru - Macieja lub Mateusza, o czym świadczy jedyny zachowany wpis proweniencyjny $^{35}$. Prawdopodobnie jako dar lub legat po śmierci mnicha wolumin został włączony do biblioteki klasztornej.

Podsumowując powyższy wywód trzeba zauważyć, że wszystkie opisane superekslibrisy przypadają na okres szesnastego stulecia czyli na czas ich rozkwitu w Polsce. Stanowiły one własność lekarza królewskiego Piotra Wedelickiego i prawdopodobnie hierarchy kościelnego Jana Lubrańskiego - renesansowych bibliofilów. Do tej pory w literaturze znano tylko jedną bądź kilka opraw z wyciskami tych superekslibrisów, co sprawia, że opisane wyżej obiekty zyskują na wartości badawczej. Niewątpliwie uzupełniają one dotychczasową wiedzę, na temat księgozbiorów ich właścicieli, które nadal czekają na wnikliwe opracowanie.

\section{TLOKI}

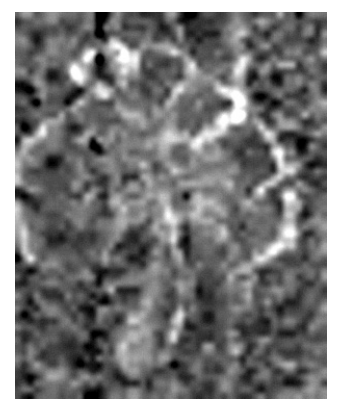

\section{listek}

\footnotetext{
${ }^{34}$ Wagner, Inkunabut, s. 315-316; tenże, Relikt, s. 61-62.

${ }^{35}$ AAG, sygn. Inc. 116: "Fr(atr)is Math(aeus/ias) C(onventus) L(ubinensis)"
} 

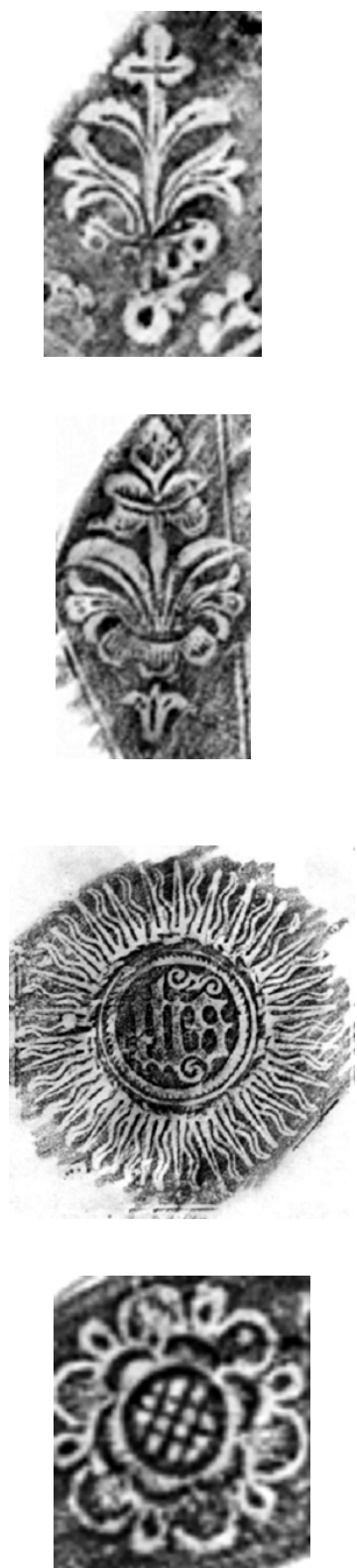

kwiaton

kwiaton 2

chrystogram w glorii promienistej

rozeta

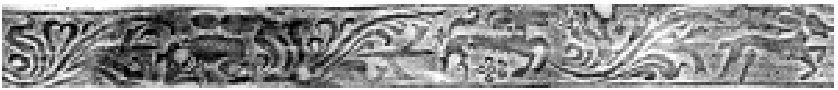

ornament arbor vitae 


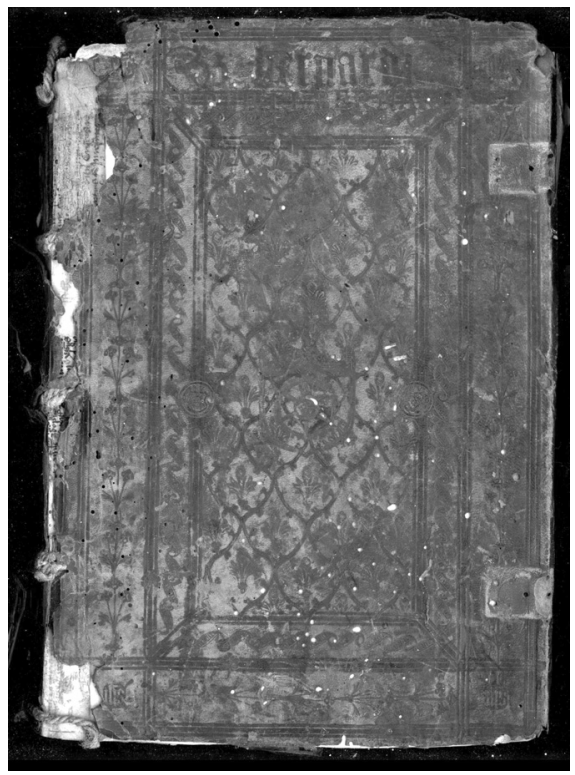

1. Górna okładzina oprawy inkunabułu należącego do Piotra Wedelickiego z Obornik, introligator Dwóch Mszałów Krakowskich i prawdopodobnie Maciej z Przasnysza, 2. dwudziestolecie XVI w., AAG, sygn. Inc. 241. Fot. R. Franczak.

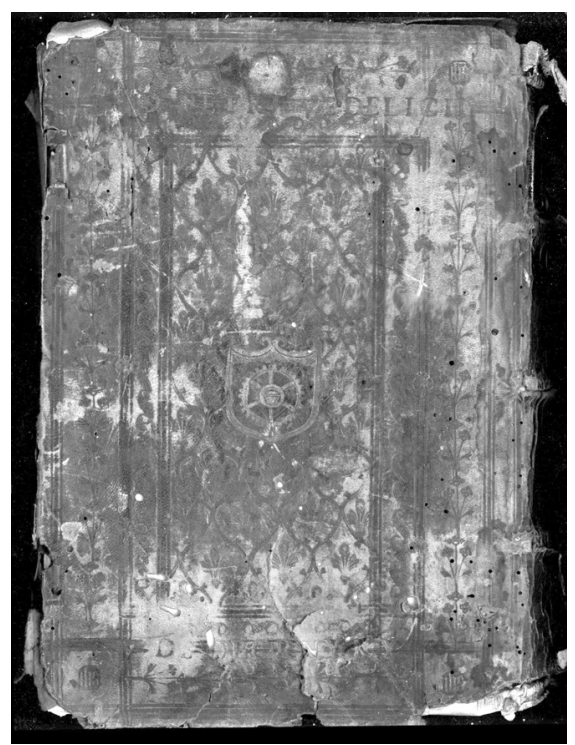

2. Dolna okładzina oprawy inkunabułu należącego do Piotra Wedelickiego z Obornik, introligator Dwóch Mszałów Krakowskich i prawdopodobnie Maciej z Przasnysza, 2. dwudziestolecie XVI w., AAG, sygn. Inc. 241, Fot. R. Franczak. 


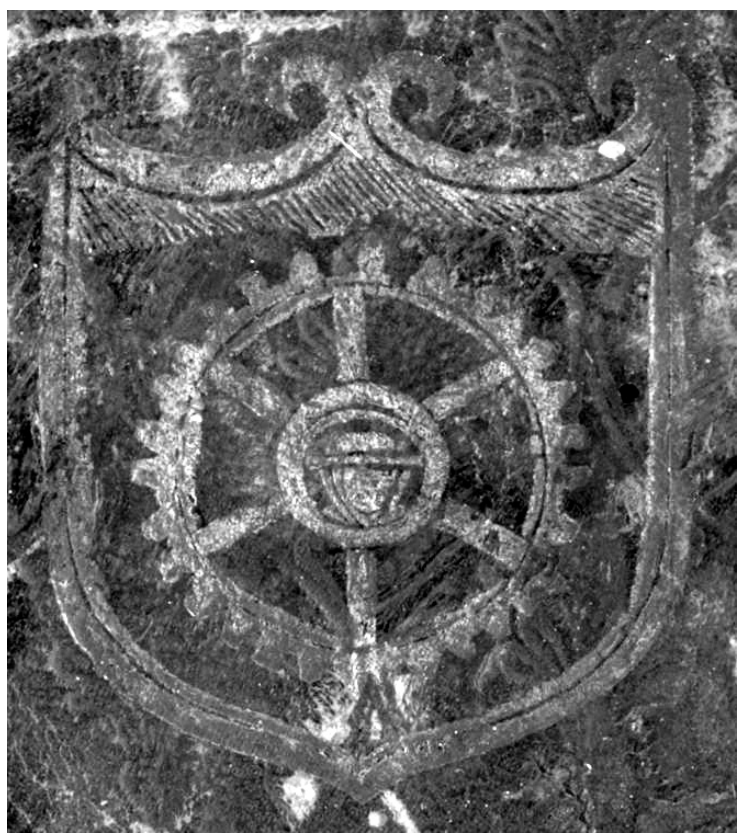

3. Superekslibris Piotra Wedelickiego z Obornik, 2. dwudziestolecie XVI w., AAG, sygn. Inc. 241. Fot. R. Franczak.

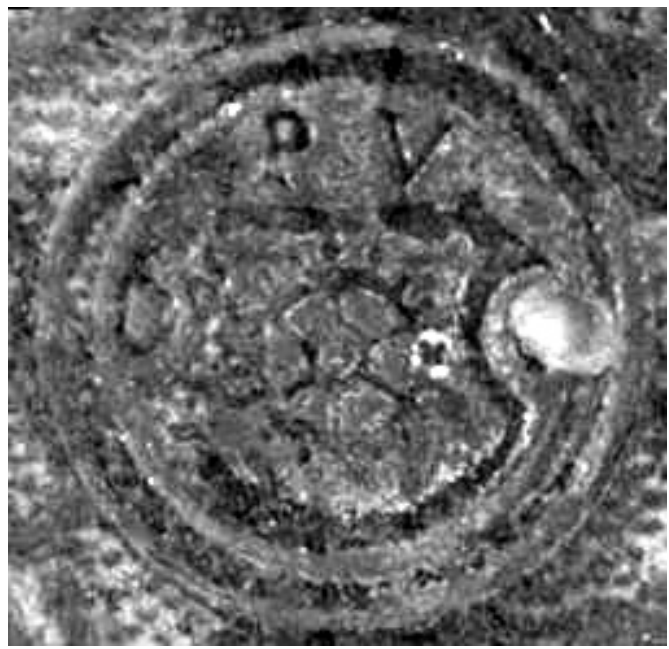

4. Superekslibris w formie sygnetowej Piotra Wedelickiego z Obornik, 2. dwudziestolecie XVI w., AAG, sygn. Inc. 241. Fot. Radosław Franczak. 


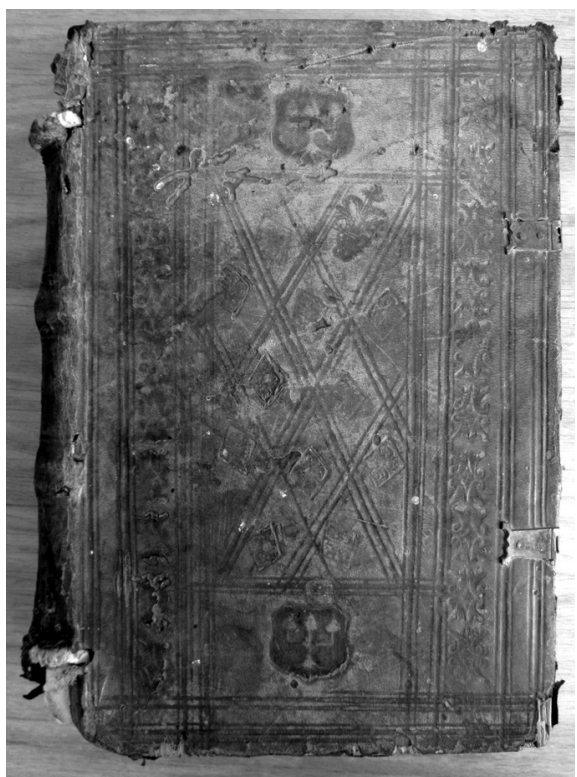

5. Górna okładzina oprawy inkunabułu należącego prawdopodobnie do bpa Jana Lubrańskiego, poznański introligator z gmerkiem „małpka ze zwierciadłem", koniec XV w. - 1. dwudziestolecie XVI wieku, AAG, sygn. Inc. 116. Fot. R. Franczak.

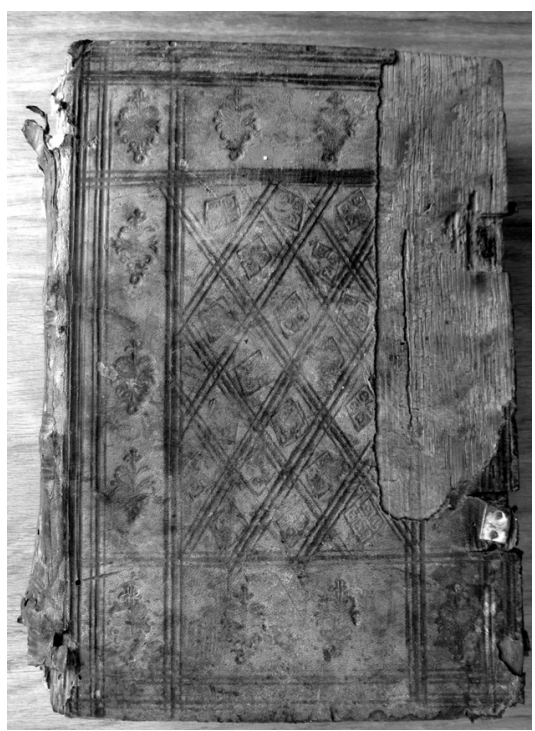

6. Dolna okładzina oprawy inkunabułu należącego prawdopodobnie do bpa Jana Lubrańskiego, poznański introligator z gmerkiem „małpka ze zwierciadłem”, koniec XV w. - 1. dwudziestolecie XVI w., AAG, , sygn. Inc. 116. Fot. R. Franczak. 


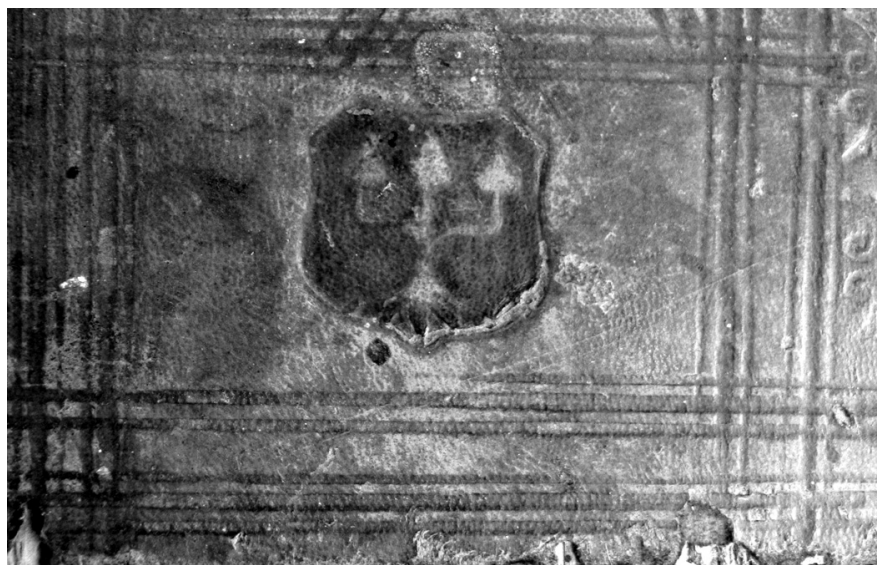

7. Prawdopodobny superekslibris bpa Jana Lubrańskiego, koniec XV wieku - 1. dwudziestolecie XVI w., AAG, sygn. Inc. 116. Fot. R. Franczak.

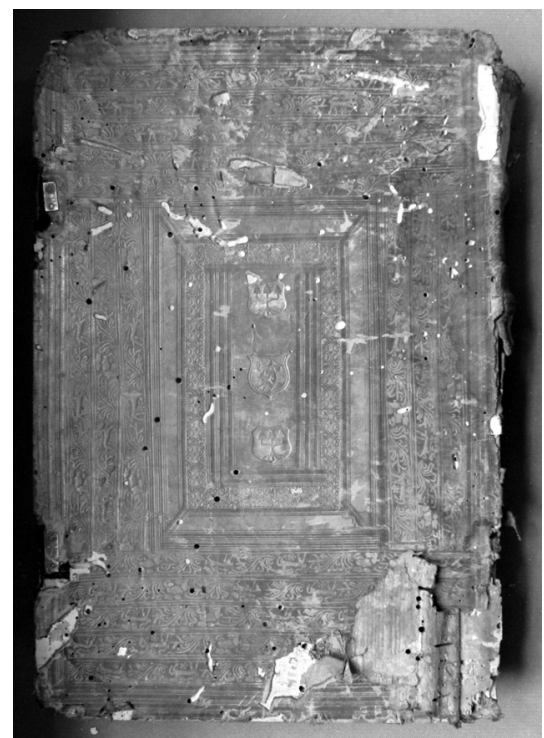

8. Dolna okładzina oprawy starodruku, introligator z gmerkiem „,małpka ze zwierciadłem", pocz. XVI w., AAG, sygn. BK3241. Fot. T. Kawaler. 


\section{BIBLIOGRAFIA}

\section{Źródła}

Archiwum Archidiecezjalne w Gnieźnie (AAG)

sygn. BK974; BK6087, BK6457, Inc. 116, Inc. 211, Inc. 212, Inc. 241.

Archiwum Archidiecezjalne w Poznaniu

sygn. Inc. 306; CP 35; Rejencja w Poznaniu, sygn. 3912.

Biblioteka Poznańskiego Towarzystwa Przyjaciół Nauk

sygn. 11642. I adl. 11643. I.

Biblioteka Uniwersytecka w Poznaniu, sygn. SD3463 III.

Biblioteka Jagiellońska, sygn. Przyb. 115/80.

Acta Capitulorum saeculi XVI selecta, T. I, wyd. B. Ulanowski, Kraków 1894.

\section{Opracowania}

Chwalewik E., Exlibrisy polskie szesnastego i siedemnastego wieku, Wrocław 1955.

Formanowicz L., Katalog inkunabułów biblioteki kapitulnej w Gnieźnie, Poznań 1939.

Grzybowski S., Kiszewski Stanisław, w: Polski Słownik Biograficzny, t. 31, Kraków-Warszawa-Wrocław 1966-1967, s. 507.

Hajdukiewicz L., Lubrański Jan h. Godziemba, w: Polski Słownik Biograficzny, t. 17, Wrocław-Warszawa-Kraków-Gdańsk 1973, s. 81-84.

Hobson A., Humanists and bookbinders, Cambridge 1992.

Jezierski A., Klasztor benedyktyński w Lubiniu, Poznań 1915.

Kantak K., Spis książek z XV wieku Ksiąznicy Seminarjum Duchownego w Poznaniu. Część pierwsza (dokończenie), „Rocznik Towarzystwa Przyjaciół Nauk Poznańskiego", 46 (1919) s. 243-311.

Leeuwen J. S., The Golden Age of Bookbindings in Cracow 1400-1600, Kraków 2011.

Lewicka-Kamińska A., Z dziejów staropolskiej oprawy książkowej, maszynopis/rękopis, Biblioteka Jagiellońska, sygn. Przyb. 33/80, Przyb. 36/80.

Marciniak R., Biblioteka biskupa Jana Lubrańskiego, „Kronika Miasta Poznania”, 2 (1999) s. 111-126.

Miaskowski K., Piotr Wedelicjusz z Obornik, „Rocznik Towarzystwa Przyjaciół Nauk w Poznaniu", 34 (1908) s. 169-212.

Ochmańska A., Prywatne księgozbiory wielkopolskie XVI w., „Biblioteka”, 2 (1998).

Ostrowski J., Bibljoteka Klasztoru Benedyktynów w Lubiniu, w: Bibljoteki Wielkopolskie i Pomorskie, red. S. Vrtel-Wierczyński, Poznań 1929.

Pokora P., Muraszko M., Skarby drukarstwa i introligatorstwa ze zbiorów dawnej Biblioteki Katedralnej w Gnieźnie. Katalog wystawy w Bibliotece Raczyńskich w Poznaniu, Poznań 5-30 maja 2015, Poznań-Gniezno 2015.

Rył J., Katalog inkunabułów zespołu Seminaryjnego Biblioteki Katedralnej w Gnieźnie, „Archiwa Biblioteki i Muzea Kościelne”, 25 (1972) s. 115-208.

Sobkowski L., O Benedyktynach Lubińskich w Starym Gostyniu, Poznań 1912.

Sokołowska-Grzeszczyk K., Znaki książkowe lekarzy polskich, „,Archiwum Historii Medycyny", 44 (1981) z. 1, s. 19-76.

Urban J., Nowożytna biblioteka opactwa benedyktynów w Lubiniu, „Zeszyty Lubińskie”, 2 (1992) s. 19-27.

Urban B., Opat Lubiński Stanisław Kiszewski w świetle kroniki Barttomieja z Krzywinia, „Zeszyty Lubińskie”, 2 (1992) s. 28-38. 
Wagner A., Gotycki ornament chrystologiczny ,, arbor vitae” na tle zdobnictwa introligatorskiego $w$ Europie $i$ Polsce $w X V$-XVI w., w: Ornament i dekoracja dziet sztuki. Studia z historii sztuki, red. J. Daranowska-Łukaszewska, A. Dworzak, A. Betleja, Warszawa 2015, s. 119-132.

Wagner A., Inkunabut w oprawie z superekslibrisami Biskupa Jana Lubrańskiegona tle introligatorstwa krakowskiego i poznańskiego końca XV-poczatku XVI w., „Archiwa, Biblioteki, i Muzea Kościelne”, 102 (2014) s. 301-325.

Wagner A., Relikt humanistycznego księgozbioru, „Spotkania z Zabytkami”, 5-6 (2013) s. 60-62.

Wagner A., Superekslibris polski. Studium o kulturze bibliofilskiej i sztuce od średniowiecza do połowy XVII wieku, Toruń 2016.

Wojtkowski J., Rekonstrukcja drugiego zeszytu katalogu inkunabułów Biblioteki Kapitulnej w Gnieźnie księdza Leona Formanowicza, Lublin 1969.

\section{SUPEREKSLIBRISY DWÓCH RENESANSOWYCH BIBLIOFILÓW NA OPRAWACH INKUNABULÓW Z DAWNEJ BIBLIOTEKI BENEDYKTYNÓW W LUBINIU}

\section{Streszczenie}

Z dawnej biblioteki benedyktynów w Lubiniu kilkadziesiąt inkunabułów znajduje się obecnie w zbiorach Archiwum Archidiecezjalnego w Gnieźnie. Na ich tle wyróżniają się dwa ze względu na znajdujące się na nich wyciski superekslibrisów. Świadczą one o własności lekarza Piotra Wedelickiego oraz prawdopodobnie biskupa poznańskiego Jana Lubrańskiego- renesansowych bibliofilów. Autor na podstawie analizy superekslibrisów oraz poszczególnych zdobień określa miejsce oraz czas oprawienia woluminów.

Słowa kluczowe: Jan Lubrański; Piotr Wedelicki z Obornik; introligator z gmerkiem „małpka ze zwierciadłem”; Maciej z Przasnysza; introligator Dwóch Mszałów Krakowskich; biblioteka klasztoru benedyktynów w Lubiniu; Archiwum Archidiecezjalne w Gnieźnie; introligatorstwo; superekslibris; tegumentologia

\section{THE SUPRALIBROS OF THE TWO RENAISSANCE BIBLIOPHILES ON THE BINDINGS OF THE INCUNABULA FROM THE FORMER BENEDICTINE LIBRARY IN LUBIŃ}

\section{Summary}

Several dozen incunabula from the former Benedictine library in Lubin are held in the Archdiocesan Archive in Gniezno. Two of them are distinctive due to the supralibros they contain. These marks refer to the owners of the incunabula: doctor Piotr Wedelicki and Poznań Bishop Jana Lubrański (Renaissance bibliophiles). Analysing supralibros and ornaments, the author managed to determine where and when the volumes were bound.

Keywords: Jan Lubrański; Piotr Wedelicki of Obornik; a bookbinder with a house mark 'a monkey with a mirror'; Maciej of Przasnysz; The Bookbinder of the Two Cracow Missals; the Benedictine library in Lubin; the Archdiocesan Archive in Gniezno; bookbinding; supralibros; bookbinding studies 